\title{
Research into properties of dust from domestic central heating boiler fired with coal and solid biofuels
}

\author{
Jan Konieczyński, Bogusław Komosiński, Ewelina Cieślik*, Tomasz Konieczny, \\ Barbara Mathews, Tomasz Rachwał, Grzegorz Rzońca \\ Institute of Environmental Engineering, Polish Academy of Sciences, Poland \\ *Corresponding author's e-mail: ewelina.cieslik@ipis.zabrze.pl
}

Keywords: fly ash, biofuel combustion, emission factors, carbon profiles.

\begin{abstract}
The aim of this research was to assess the content and composition of the pollutants emitted by domestic central heating boilers equipped with an automatic underfeed fuel delivery system for the combustion chamber. The comparative research was conducted. It concerned fuel properties, flue gas parameters, contents of dust (fly ash) and gaseous substances polluting the air in the flue gases emitted from a domestic $\mathrm{CH}$ boiler burning bituminous coal, pellets from coniferous wood, cereal straw, miscanthus, and sunflower husks, coniferous tree bark, and oats and barley grain. The emission factors for dust and gaseous air pollutants were established as they are helpful to assess the contribution of such boilers in the atmospheric air pollution. When assessing the researched boiler, it was found out that despite the development in design and construction, flue gases contained fly ash with a significant EC content, which affected the air quality.
\end{abstract}

\section{Introduction}

Coal combustion encompasses a number of complicated chemical transformations, including pyrolysis, soot formation and other reactions (Chen et al. 2005). Within the first few minutes after the coal ignition, the emission level is up to 50 times higher than in the remaining part of the combustion process (Chen et al. 2005). $\mathrm{CO}_{2}, \mathrm{H}_{2} \mathrm{O}_{(\mathrm{g})}$ and dusts from the mineral substance contained in the fuel constitute the main combustion products. When the solid fuel combustion processes are conducted with inappropriate parameters or in inappropriate installations, products of the incomplete combustion (PICs) are formed. Combustion in an uncontrolled boiler contributes to the emissions of: fly ash, carbon monoxide, acid aerosols, persistent organic pollutants (POPs), such as dioxins, furans (PCDD/F), polycyclic aromatic hydrocarbons (PAHs), and micro-pollutants (coming from the incomplete thermal digestion of the organic matter), such as aliphatic and aromatic hydrocarbons, alcohols, aldehydes, ketones, carboxylic acids or chlorinated aliphatic and aromatic hydrocarbons (Szewczyńska et al. 2006, Estrellan and Iino 2010).

Solid fuel combustion in household furnaces for cooking and heating increases the PM emission and percentage of fine particles in the flue gases. The results of the research into the dust fraction composition demonstrate that over $94 \%$ of the dust particles from the coal combustion were submicron, i.e. the median of the aerodynamic diameter was below $0.3 \mu \mathrm{m}$ (Chen et al. 2005).

The emission factors were determined on the basis of the burnt dry ash-free (daf) coal for fly ash formed due to hard coal combustion in household furnaces and 20 PAHs (naphthalene, acenaphthylene, acenaphthene, fluorene, phenanthrene, anthracene, fluoranthene, pyrene, benz $[a]$ anthracene, chrysene + triphenylene, benzo $[b+j+k]$ fluoranthenes, benzo $[e]$ pyrene, benzo[ $a]$ pyrene, perylene, indeno[1,2,3-cd]pyrene, dibenz $[a, h]$ anthracene and benzo[ghi]perylene) are $12.91 \mathrm{~g} / \mathrm{kg}$ and 211 $\mathrm{mg} / \mathrm{kg}$, respectively. The values for sub-bituminous coal and anthracite are 8 and $1.3 \mathrm{~g} \mathrm{dust} / \mathrm{kg}$, respectively (Chen et al. 2005). The limited contact of the gaseous and solid phases in the furnace results in the high total carbon (TC) content in the fly ash (Zhang and Smith 2007, Szkarowski and Janta-Lipińska 2013). For example, $10-30 \%$ of the emitted TC comes from typical household furnaces in China and India (IARC 2012). The TC occurs in the emitted dust as elemental carbon or in the organic compounds. The sum of the organic (OC) and elemental carbon (EC) ranges between 1 and $10 \%$ mass in the fine dust particles coming from the emissions in the coal power stations (Watson et al. 2001). The industrial boilers demonstrate much higher coal burn-out. Consequently, the emitted solid particles have lower contents of OC, EC and organic compounds. The emission factor for the fly ash from industrial boilers may be even 100 times lower than the factor established for household furnaces (Zhang et al. 2008).

In the air, PAHs from anthropogenic sources are present nearly always in the solid phase (Geng et al. 2014). They are adsorbed on the surface of soot and respirable dust (aerodynamic diameter less than $10 \mu \mathrm{m}$ ) (Guo et al. 2003).

The wood pellet combustion results in a relatively low level of the solid particle emission (Ehrlich et al. 2007, Nussbaumer et al. 2008, Schmidl et al. 2011). Nonetheless, wood combustion contributes to the increase in the concentrations of $\mathrm{PM}_{25}$, soot, PAHs, and monosaccharide anhydrides (levoglucosan and 
mannosan) in the air (Glasius et al. 2008). The speciation of the $\mathrm{C}$ forms, in the flue gases from the wood combustion shows that the mean percentage of EC and OC was $23.4 \%$ and $76.6 \%$, respectively (Schmidl et al. 2008).

When Norwegian wood is burnt in more modern furnaces (medium firing), the emission factors for PM, EC and OC are 12.2, 0.88 and $9.9 \mathrm{~g} / \mathrm{kg}_{\text {fuel, }}$ respectively (Seljeckog, 2013). Concentrations of toxic PAHs, including the carcinogenic ones, are much higher in the dust and condensate from the incomplete wood combustion than in the soot emitted from diesel engines (Nussbaumer et al. 2008). The automatic installations for wood combustion that are well-designed and operated in a proper way provide low emissions of hydrocarbons and soot (Nussbaumer et al. 2008, Schmidl et al. 2011).

The research into the fly ash with adsorbed organic compounds helps to indicate the emission sources. The analysis of the emitted primary pollutants (precursors) allows for the assessment of the secondary reaction course and fate of the organic particles during transport in the air (Simoneit 2002).

Solid fuels are still the dominant energy source in households, which deteriorates the air quality. In Poland, approx. 50\% of households use solid fuel heating devices. Annually, they use up approx. 9.2 Tg of hard coal (CSO 2012).

Solid fuels from agricultural and forest biomass are still dominant in the segment of renewable energy sources. The biomass percentage in the energy coming from renewable energy sources was $82.4 \%$ in 2012 (CSO 2014).

The PAH emissions must be reduced to protect the ecosystem and human health (Geng et al. 2014). In the Chinese countryside, approx. 40\% of households use coal for cooking and heating. Emissions from the household coal combustion cause lung cancer in people (IARC 2012), respiratory system diseases and acute respiratory system infections (Zhang and Smith 2007). The correlation between the solid fuel combustion in households and the lung cancer risk was researched by IARC (2012) in 7 European countries (Czech Republic, Hungary, Poland, Romania, Russia, Slovakia and Great Britain). In Eastern Europe, the common use of coal and ineffective wood combustion in households hinders the air quality improvement (Kiesewettera et al. 2015). It is necessary to conduct further research into the properties of the dust emitted during fuel combustion when it comes to the risk posed to the inhabitants' health (Hitzenberger and Tursic 2008).

The aim of this research was to assess the content and composition of the pollutants emitted by domestic central heating water boilers $(\mathrm{CH})$ equipped with an automatic underfeed fuel delivery system for the combustion chamber. The fuel feeder is an improvement in the solid fuel combustion in the fixed bed affecting the pollutant reduction. Nonetheless, its use does not fully prevent the formation of the incomplete and imperfect combustion products. The cognitive objective was to investigate the contents of inorganic carbon (carbonate one), $\mathrm{OC}$ and $\mathrm{EC}$ in the dust emitted from the furnaces fired with bituminous coal, wood and forest and agricultural biomass fuels. Understanding the $\mathrm{C}$ forms in the dust emitted from the energy sources fired with solid hydrocarbon fuels together with the research into the $\mathrm{C}$ carbon occurring into the atmospheric dust will contribute to a better assessment of the emission sources in the air pollution with dust in different areas.

In order to accomplish the defined objectives, it was necessary to use a research boiler installation (RI) with a central heating water boiler fired with solid fuels. The boiler was not an experimental device but a product to be used in small residential houses. Using the commercial boiler provided the proper course of the fuel combustion in the fully controlled long-time measurement-research cycles.

\section{Materials and methods}

The following fuels were selected for investigation: Silesian bituminous coal with particle size of 8-24 mm (low ash and sulphur content), pellets from coniferous wood (mixture of pine and spruce), pellets from cereal straw, miscanthus (Miscanthus giganteus), sunflower hulls (Helianthus annuus L), and also oats (Avena L.) and barley (Hordeum L.) grains, and coniferous tree bark. The researched fuel samples were analysed for the moisture content (PN-G-04511). The ash content was determined with the gravimetric method (PN-G-04512). The contents of carbon, total hydrogen, total nitrogen and total sulphur were determined with the hightemperature detection coupled with IR detection (PN-G-04584 and PN-G-04571). The chlorine content was determined with the titration method (PN-ISO 587). The oxygen content was calculated. Additionally, the heat of combustion was determined with the calorimetric method and the heating value was calculated (PNG-04513 and PN-ISO 1928). The analyses were conducted in accordance with the standards in force. Table 1 presents the analysis results.

The measurements were taken in the $\mathrm{CH}$ boiler $(18-\mathrm{kW}$ power, $85 \%$ efficiency) with a retort furnace, automatic fuel feeder, forced draught fan for combustion air and $0.16-\mathrm{m}^{3}$ fuel storage bin. The research boiler installation was equipped with an external heat exchanger installation, sampling points for flue gas and fly ash for chemical analyses and physicochemical research, and control-measurement instrument system. The flue gases passed through the duct into the atmospheric air without being dedusted. The measurement system included: a device for controlling and steering the boiler work process, Emiotest gravimetric dust meter, aspiration probe with internal dust filtration, S-type Pitot tube with Emiotest 2598 data recorder, and DX-4000 Gasmet flue gas analyser $\left(\mathrm{O}_{2}, \mathrm{SO}_{2}, \mathrm{NO}, \mathrm{NO}_{2}, \mathrm{CO}\right.$, $\mathrm{CO}_{2}, \mathrm{H}_{2} \mathrm{O}$ ). The applied control-measurement and analytical apparatus let the researchers continuously measure the main process parameters and the basic flue gas composition.

5 research series of the fuel combustion were performed during the investigation. They lasted 24 hours. The RI was not equipped with a device for the continuous measurement of the fly ash emission. Consequently, to determine the emission factor, it was necessary to take into account the quantities measured with both continuous measurements of the main flue gas stream from the boiler and periodical (manual) measurements when the fly ash was sampled from the separated side flue gas stream. The flue gas velocity was measured with determining the point dynamic pressures in the examined measurement cross-section. The measurement was carried out on the side flue gas stream separated from the main one. It was based on the isokinetic aspiration of the flue gas stream and separation of the solid samples from this stream on the filter. The dust mass was established with weighing the filter before and after the measurement. The following filters were applied: P-84 filter bags, GF/A filters from the borosilicate glass without binder (WHATMAN), and QM-A quartz filters 


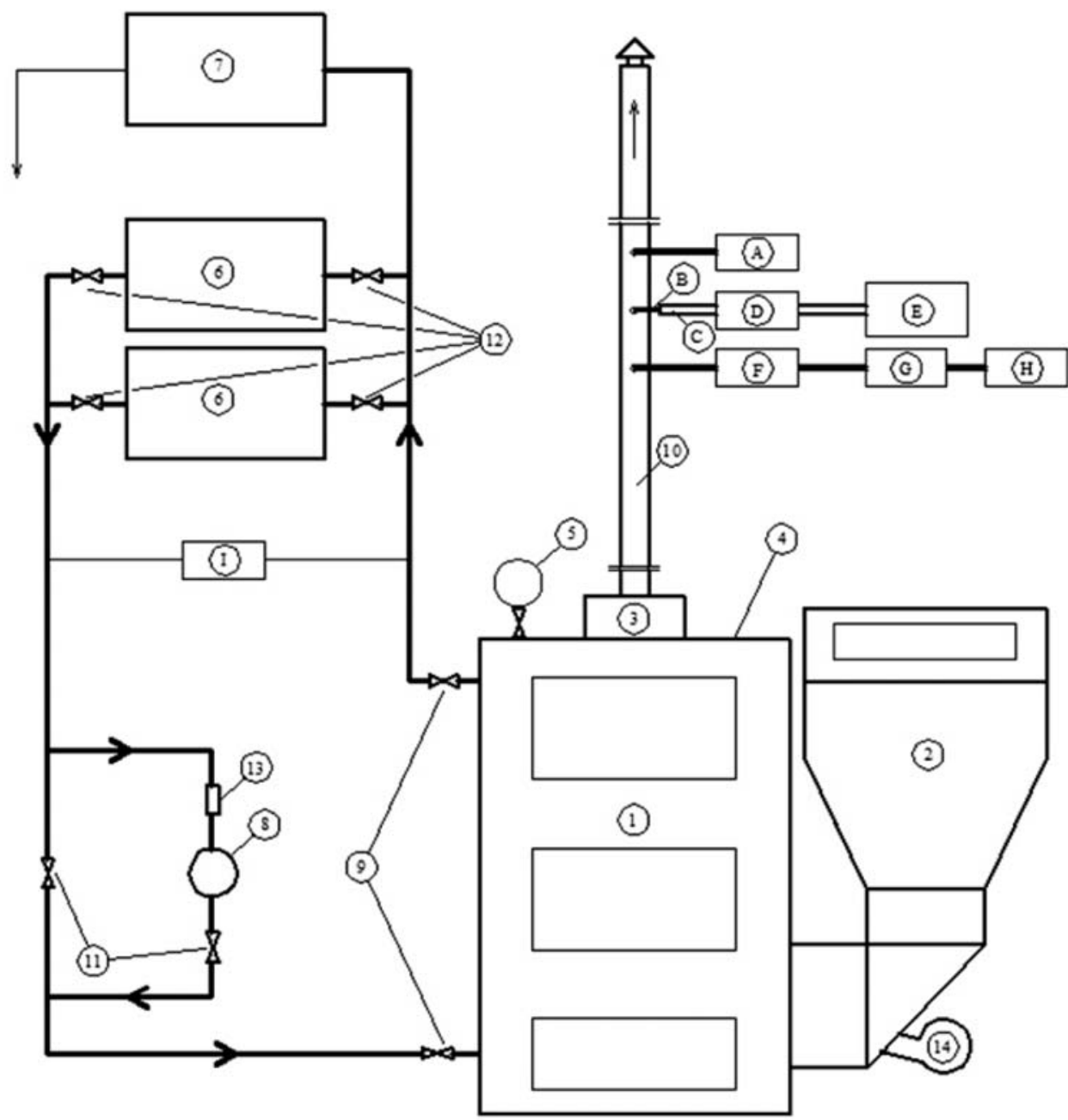

Fig. 1. Schematic diagram of the research boiler installation

Boiler schematic diagram: 1 - heating boiler, 2 - fuel feeder, 3 - boiler work steering module, 4 - liquid temperature measurement at the boiler outlet, 5 - liquid pressure measurement in the system, 6 - heat exchanger, 7 - expansion tank, 8 - pump enforcing the liquid circulation in the system, 9 - shut-off valves, 10 - duct, 11 - valves regulating the liquid flow in the system, 12 - valves shutting off the liquid flow through the external heat exchanger, 13 - filter in front of the pump, 14 - forced draught fan.

Measurement apparatus: A - micromanometer and thermocouple, B - aspiration probe, C - heated pipe, D - conditioner, E - gas analyzer Gasmet DX 4000, F - dryer, G - dust concentration meter EMIOTEST 2598, H - pump, I - heat gauge

(WHATMAN) (PN-Z-04030-07). The $\mathrm{CO}_{2}, \mathrm{CO}, \mathrm{H}_{2} \mathrm{O}, \mathrm{SO}_{2}$ and NO concentrations were determined with the DX-4000 Gasmet flue gas analyser (PN-ISO 10396). The data was recorded in 1-minute intervals. The above-mentioned measurements were carried out with the referential methods accredited at the Polish Centre of Accreditation.

The fly ash samples, collected onto the quartz filters, were analysed for the OC, EC and TC content with the thermal-optical method. The analysis was conducted with the Sunset Laboratory Inc. analyser.

The averaged sample was collected from the bottom ashes and slags in order to measure the solid residue contents coming from the combustion process. The content of the unburnt fuel in the combustion residue was determined in the sample.

\section{Results and discussion}

For the environmental assessment of the investigated $\mathrm{CH}$ boiler, the pollutant emission from this boiler was compared with the emission from traditional energy installations, such as coal household furnaces and energy boilers in power stations, heating stations and combined heat and power stations. The comparison concerned emissions of fly ash, carbon monoxide, sulphur dioxide and nitrogen oxides. It did not concern carbon dioxide as in most cases forest or agricultural biomass fuels (i.e. renewable fuels) were investigated. The researchers decided to put together household devices, large-scale installations equipped with dust collection devices (utility boiler), and the circulating fluidized bed boiler (CFB) with the desulphurization with a dry additive (Table 2).

In most of the tests, it was found out that the investigated boiler fired with selected bituminous coal emitted more fly ash than the traditional household furnaces. The application of the fuel feeder and mechanical combustion air blow in the examined boiler resulted in the fact that no optically dense flue gas stream was observed even though it normally accompanies traditional household furnaces after a large fuel portion is introduced onto the grate. The measured fly ash 


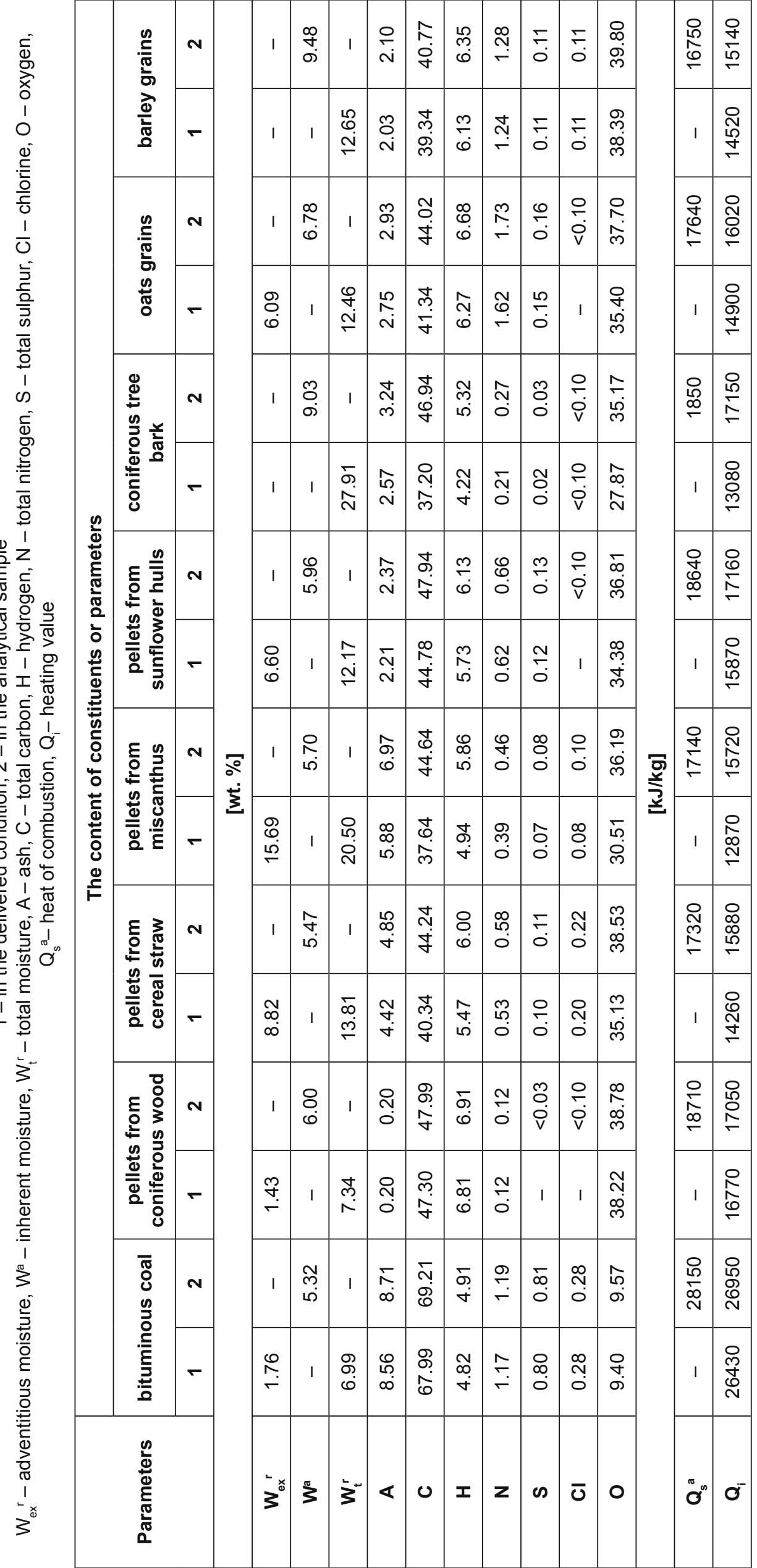


emission factor (Table 3) is within the value range given by Chen (2005). In the examined boiler, the combustion air blow increased the combustion completeness, which was confirmed with the emission factor for carbon monoxide that was a few times lower (Table 3). On the other hand, the air blow increases the fly ash emission.

During the research, the $\mathrm{C}$ carbon forms in the fly ash were analysed, which might be helpful to assess the soot emission in the fly ash. Amorphous EC (contained in the fly ash) may be the toxic and carcinogenic substance carrier. The OC might be the reason why the secondary air pollutants appeared. Due to the influence on the air condition, it is necessary to analyse the $\mathrm{C}$ carbon forms in the emitted fly ash.

Table 4 presents the OC and EC percentage in the researched fly ashes introduced into the air. The data on the industrial boilers come from the measurements taken by the authors in another project. It was discovered that the fly ash from bituminous coal used in the $\mathrm{CH}$ boiler was dominated by EC (72\%). OC dominated in the fly ash from the pulverized coal-fired boiler and fluidized bed boiler and collected downstream from the electrostatic precipitator. The soot percentage was approx. $30 \%$. On the other hand, EC dominated in the fly ash from the mechanical grate collected downstream from the multicyclone (approx. 90.8\%). The OC and EC percentage was similar in the fly ash from pellets made from straw, sunflower and miscanthus, coniferous tree bark and barley grains. OC dominated in the fly ash from the oats grain combustion (over 98\%) and coniferous wood pellets (over 79\%). The second of the mentioned results is similar to those obtained by Seljeckog (2013). The quoted Seljeckog presents data on the wood combustion where the OC percentage in the emitted fly ash is 10 times higher than the EC percentage. The difference may be explained with the combustion conditions observed in the researched $\mathrm{CH}$ boiler. The research into the combustion in the discussed domestic $\mathrm{CH}$ boiler demonstrated that the combustion was incomplete and poorer than the combustion in the pulverized coal and fluidized bed boilers. The EC percentage in the emitted fly ash was $72,1 \%$ for the first source, and $30.7-33.2 \%$ for the

Table 2. Emission factors for the main air pollutants during bituminous coal combustion in various furnaces [kg/Mg]

\begin{tabular}{|c|c|c|c|c|}
\hline Furnace type & Fly ash & $\mathrm{SO}_{2}$ & $\mathrm{NO}_{2}$ & CO \\
\hline $\begin{array}{c}\text { Pulverized coal-fired boiler* } \\
\text { flue gases dedusted with ESP of an older type, without } \\
\text { desulphurization }\end{array}$ & 0.82 & 16 & 6 & 0.3 \\
\hline $\begin{array}{c}\text { Mechanical grate boiler* } \\
\text { Flue gases dedusted with the multicyclone system, } \\
\text { without desulphurization }\end{array}$ & 9.0 & 17 & 5 & 1.5 \\
\hline $\begin{array}{l}\text { Circulating fluidized bed boiler* } \\
\text { flue gases dedusted with modern ESP, desulphurization } \\
\text { with dry additive }\end{array}$ & 0.160 & 4.29 & 1.67 & 0.41 \\
\hline Household furnaces* & 5.4 & 14.4 & 1.5 & 100 \\
\hline $\begin{array}{l}\text { Tested domestic central heating boiler } \\
\text { different bituminous coal }\end{array}$ & $4.3-10.2$ & $9.6-11.2$ & $4.6-5.6$ & $14.1-33.8$ \\
\hline
\end{tabular}

* (Konieczyński and Pasoń-Konieczyńska 1999)

ESP - electrostatic precipitator

Table 3. Comparison of the emission factors for pollutants during combustion of the examined fuels

\begin{tabular}{|c|c|c|c|c|c|c|c|c|c|}
\hline Parameter & Unit & 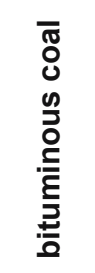 & 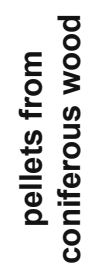 & 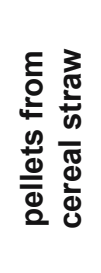 & 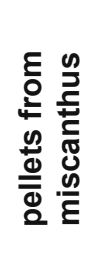 & 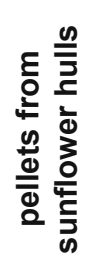 & 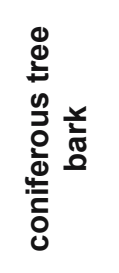 & 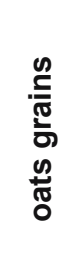 & $\begin{array}{l}\frac{n}{\bar{E}} \\
\frac{\sqrt[T]{0}}{\sigma} \\
\frac{7}{\frac{0}{\pi}} \\
\frac{\pi}{0}\end{array}$ \\
\hline Fly ash & \multirow{4}{*}{$\mathrm{kg} / \mathrm{Mg}$} & 10.20 & 1.15 & 2.71 & 0.97 & 2.50 & 5.78 & 0.31 & 1.41 \\
\hline $\mathrm{SO}_{2}$ & & 9.58 & 0.16 & 1.18 & 1.26 & 0.26 & 0.77 & 2.35 & 2.49 \\
\hline $\mathrm{NO}_{\mathrm{x}}$ as $\mathrm{NO}_{2}$ & & 4.66 & 0.99 & 2.81 & 3.24 & 0.31 & 8.23 & 5.30 & 3.18 \\
\hline $\mathrm{CO}$ & & 33.77 & 28.52 & 27.33 & 12.19 & 84.38 & 140.88 & 9.64 & 18.71 \\
\hline Fly ash & \multirow{4}{*}{$\mathrm{g} / \mathrm{MJ}$} & 0.39 & 0.07 & 0.19 & 0.08 & 0.16 & 0.44 & 0.02 & 0.10 \\
\hline $\mathrm{SO}_{2}$ & & 0.36 & 0.01 & 0.08 & 0.10 & 0.02 & 0.06 & 0.16 & 0.17 \\
\hline $\mathrm{NO}_{\mathrm{x}}$ as $\mathrm{NO}_{2}$ & & 0.18 & 0.06 & 0.20 & 0.25 & 0.02 & 0.63 & 0.36 & 0.22 \\
\hline $\mathrm{CO}$ & & 1.28 & 1.70 & 1.92 & 0.95 & 5.32 & 10.77 & 0.65 & 1.29 \\
\hline
\end{tabular}


Table 4. Contents and percentage of the $C$ forms in the emitted fly ash*

\begin{tabular}{|c|c|c|c|c|c|c|}
\hline \multirow{2}{*}{ Boiler } & \multirow{2}{*}{ Fuel } & \multicolumn{2}{|c|}{ OC } & \multicolumn{2}{|c|}{ EC } & \multirow{2}{*}{$\frac{\mathrm{TC}}{(\mathrm{mg} / \mathrm{g})}$} \\
\hline & & $(\mathrm{mg} / \mathrm{g})$ & $\%$ & $(\mathrm{mg} / \mathrm{g})$ & $\%$ & \\
\hline Pulverised coal, 200 MW & \multirow{4}{*}{ bituminous coal } & 47.83 & 66.81 & 23.35 & 33.19 & 71.17 \\
\hline Mechanical grate, water, 29 MW & & 25.52 & 23.54 & 82.92 & 76.46 & 108.45 \\
\hline CFB, $295 \mathrm{MW}_{\mathrm{t}}$ & & 22.76 & 69.30 & 10.08 & 30.70 & 32.85 \\
\hline $\begin{array}{l}\text { Mechanical grate, steam, } \\
\text { max. continuous rating: } 9.7 \mathrm{~kg} / \mathrm{s}\end{array}$ & & 8.46 & 9.23 & 83.20 & 90.77 & 91.66 \\
\hline \multirow{8}{*}{$\begin{array}{l}\text { tested domestic central } \\
\text { heating boiler }\end{array}$} & bituminous coal & 124.18 & 27.90 & 334.14 & 72.10 & 458.32 \\
\hline & pellets from coniferous wood & ND & 79.36 & ND & 20.64 & ND \\
\hline & pellets from cereal straw & 43.94 & 48.55 & 46.57 & 51.45 & 90.51 \\
\hline & pellets from miscanthus & 112.80 & 51.15 & 107.73 & 48.85 & 220.53 \\
\hline & pellets from sunflower hulls & 28.04 & 46.01 & 32.90 & 53.99 & 60.93 \\
\hline & coniferous tree bark & 112.56 & 57.66 & 82.67 & 42.34 & 195.24 \\
\hline & oats grains & 509.32 & 98.35 & 8.53 & 1.65 & 517.84 \\
\hline & barley grains & 22.20 & 56.07 & 17.39 & 43.93 & 39.59 \\
\hline
\end{tabular}

* Own Research

ND - no data

other sources. Large EC percentage in the fly ash emitted from the examined $\mathrm{CH}$ boiler is compliant with the reports on the negative effects of the coal combustion in household furnaces (Zhang and Smith 2007, IARC 2012). The research results from the oats grain combustion make a separate case. On the other hand, the results for the boiler with a mechanical grate confirmed the correlation between the EC percentage in the fly ash and the combustion completeness. It must be emphasized that the emission of the dust containing $\mathrm{OC}$ and $\mathrm{EC}$ inhibits or prevents the improvement in the air quality condition in the residential emission regions. The dust collection devices, commonly used in the large energy production installations, constitute the real method for reducing the fly ash emission from the coal furnaces.

The agricultural or forest biomass fuel combustion does not cause significant fly ash emission. Such a situation is usually related to the low ash content in the fuel. The only exception was the tree bark for which the dust emission factor was $5.78 \mathrm{~kg} / \mathrm{Mg}_{\text {fuel }}$. For the remaining solid biofuels, the emission factor values ranged between 0.31 (oats grain) and $2.71 \mathrm{~kg} / \mathrm{Mg}_{\text {fuel }}$ (straw pellets). The measured emission factor for fly ash in wood is lower than the value given by Seljeckog (2013) but it concerns coniferous wood with low ash content. The own results are compliant with the ash emission assessment done for the wood combustion by Ehrlich (2007), Nussbaumer (2008), and Schmidl (2011).

The sulphur dioxide emission factors determined for the researched boiler were lower than the factors for traditional household furnaces, which resulted from the lower sulphur content in the investigated bituminous coal. On the other hand, the nitrogen oxide factors were three times higher than the factors for household furnaces and comparable with the values determined for boilers with the pulverized coal-fired furnace or mechanical bed. Such a situation could be explained with higher availability of the air in the investigated boiler. As it is known, the combustion air stream is appropriately dosed in the primary methods for reducing the nitrogen oxide emission from coal furnaces in order to create the reduction conditions in the first phase.

For the researched boiler, the carbon monoxide emission factors were lower by one order of magnitude when compared with household furnaces and higher by one order of magnitude when compared with mechanical grate boilers. This resulted from using the air blow into the combustion chamber when the fuel portion was fed into it, which increased the combustion completeness in comparison with the household furnaces.

The sulphur dioxide emission factors for the solid biomass fuel combustion were between 0.16 (coniferous wood pellets) to $2.49 \mathrm{~kg} / \mathrm{Mg}_{\text {fuel }}$ (barley grain). In other words, they were much lower than the analogous factors obtained for the compared boilers, including CFB boilers with the desulphurization with a dry additive. The situation resulted from the fact that the sulphur content in the researched biofuels was much lower than in bituminous coal.

The nitrogen oxide emission factors for the solid biomass combustion ranged between 0.31 (miscanthus pellets) and $8.33 \mathrm{~kg} / \mathrm{Mg}_{\text {fuel }}$ (coniferous tree bark). The nitrogen oxide emission factor for the coniferous tree bark was higher than for bituminous coal. The situation might be related to the used boiler (spreader stoker). For coniferous wood and sunflower hull pellets, the emission factor was lower than for bituminous coal. For the remaining fuels, the values were comparable.

The carbon monoxide emission factors for the solid biomass combustion ranged between 9.64 (oats grain) and $140.88 \mathrm{~kg} / \mathrm{Mg}_{\text {fuel }}$ (coniferous tree bark). The carbon monoxide emission factor for the combustion of sunflower hull pellets or coniferous tree bark was much higher than for the remaining biofuels. For the tree bark combustion, it was even higher than the carbon monoxide emission factor for the coal combustion in household furnaces. The findings enable the researchers to state that the emission factors for fly ash, 
carbon monoxide, sulphur dioxide and nitrogen oxides that were preliminarily determined for these fuels do not raise any doubts from the environmental point of view. The large-scale utilization of certain solid biomass fuels in the distributed generation systems in the thinly populated areas will not threaten the air purity.

When taking into consideration the available forecast on the participation of solid biofuels in the national energy economy, it seems that wood chips and pellets, straw pellets or straw in other forms (Czop and Kajda-Szcześniak 2013), as well as pellets from energy crops (e.g. miscanthus) may really be widely used. Their technical potential for being fuels is estimated in the following way: waste wood from forests (approx. 200 PJ), untrapped straw (approx. 114 PJ) and energy crops (approx. 130 PJ) (Bartoszewicz-Burczy 2012).

The following mean heating values may be considered: bituminous coal - $21.4 \mathrm{MJ} / \mathrm{kg}$; wood pellets $-16.7 \mathrm{MJ} / \mathrm{kg}$; straw pellets - $14.3 \mathrm{MJ} / \mathrm{kg}$; and miscanthus pellets - $12.9 \mathrm{MJ} / \mathrm{kg}$. It may also be assumed that approx. $50 \%$ of the estimated technical potential of the above-mentioned biomass could be used for energy needs. Taking these assumptions into account, it would be possible to calculate how much the emissions of sulphur dioxide, carbon dioxide and dust would decrease if the biomass fuels were used in the distributed generation systems instead of bituminous coal.

Annually, the combustion of $6 \mathrm{Tg}$ of coniferous wood pellets would replace approx. 4.7 Tg of bituminous coal. Approx. 4 $\mathrm{Tg}$ of the straw pellets and approx. $5 \mathrm{Tg}$ of miscanthus pellets would replace approx. $2.7 \mathrm{Tg}$ and $3 \mathrm{Tg}$ of bituminous coal, respectively. In total, it would give the replacement of $10.4 \mathrm{Tg}$ of bituminous coal. In this way, the emissions of the fly ash and sulphur dioxide could be reduced by $50 \mathrm{Gg}$ and $90 \mathrm{Gg}$, respectively. The carbon dioxide emission would be approx. $20 \mathrm{Tg}$. The last figure takes into consideration the unavoidable carbon dioxide emission when biomass is obtained, transported and transformed into the fuel.

\section{Summary and conclusions}

The combustion of selected bituminous coal in a domestic $\mathrm{CH}$ boiler with a fuel feeder and combustion air blow brings about the fly ash emission that is not lower than the emission from the traditional coal furnaces. Consequently, it does not prevent the air quality degradation, particularly in the heavily populated regions.

The fly ash emitted from the domestic $\mathrm{CH}$ boiler contains large contents of the $\mathrm{C}$ carbon. The $\mathrm{TC}$ content in the fly ash from bituminous coal is approx. $460 \mathrm{mg} / \mathrm{g}$ with the dominant EC percentage ( $72 \%$ of the mass). High content of TC occurred also in the fly ash from the oats grain combustion (approx. $520 \mathrm{mg} / \mathrm{g}$ ), with the dominant OC percentage $(98 \%$ of the mass). It was observed that the $\mathrm{OC}$ and $\mathrm{EC}$ percentage was similar in the fly ash from pellets made from straw, sunflower and miscanthus, coniferous tree bark and barley grains

The combustion of solid fuels from the agricultural and forest biomass (wood pellets; straw pellets or straw in other forms; pellets from energy crops, such as miscanthus) does not raise any doubts from the environmental viewpoint in terms of the emission factors (dust, carbon monoxide, sulphur and nitrogen oxides) established for these fuels. When they are applied on a large scale in the distributed generation systems (in appropriate boilers) in thinly populated areas, they will not pose a threat to the air quality. Optionally, the dust collection devices may be used with higher power boilers. Wood can be burnt in an environmentally safer way when the devices for the preliminary degassing of wood are used and the formed wood gas is burnt. The final assessment of the solid biomass fuel usability requires the research into the contents of organic compounds (including PAHs) in the emitted flue gases and fly ash.

\section{Acknowledgements}

This work was supported by the Institute of Environmental Engineering, Polish Academy of Sciences (Zabrze, Poland) in the framework of Statutory Studies (1a-104/12/13/14).

\section{References}

Bartoszewicz-Burczy, H. (2012). Biomass potential and its energy utilization in the Central European countries, Energetyka, (12), pp. 860-866. (in Polish)

Chen, Y, Sheng, G, Bi, X, Feng, Y, Mai, B \& Fu, J. (2005). Emission factors for carbonaceous particles and polycyclic aromatic hydrocarbons from residential coal combustion in China, Environmental Science and Technology, 39(6), pp. 1861-1867.

CSO (Central Statistical Office of Poland); Energy consumption in households in 2009, Warsaw 2012.

CSO (Central Statistical Office of Poland); Energy from renewable sources in 2013, Warsaw 2014.

Czop, M. \& Kajda-Szcześniak, M. (2013). Environemental impact of straw based fuel combustion, Archives Of Environmental Protection, 39(4), pp. 71-80.

Ehrlich, C., Noll, G. \& Kalkoff, W.D. (2007). Determining PM-emission fractions (PM10, PM2.5, PM1.0) from small-scale combustion units and domestic stoves using different types of fuels including bio fuels like wood pellets and energy grain. (http://rook.woelmuis.nl/Documenten/DATA/EHRLICH_.PDF. (09 April 2015)).

Estrellan, C.R. \& Iino, F. (2010). Toxic emissions from open burning, Chemosphere, 80, pp. 193-207.

Geng, C., Chen, J., Yang, X., L. Ren, L., Yin, B., Liu, X. \& Bai, Z. (2014). Emission factors of polycyclic aromatic hydrocarbons from domestic coal combustion in China, Journal of Environmental Sciences, 26(1), pp. 160-166.

Glasius, M., Tetzel, M., Wahlin, P., Bossy, R., Stubkjćr, J., Hertel, O. \& Palmgren, F. (2008). Characterization of particles from residential wood combustion and modelling of spatial variation in a low-strength emission area, Atmospheric Environment, 42(37), pp. 8686-8697.

Guo, H., Lee, S.C., Ho, K.F., Wang, X.M. \& Zou, S.C. (2003). Particle-associated polycyclic aromatic hydrocarbons in urban air of Hong Kong, Atmospheric Environment, 37(38), pp. 5307-5317.

Hitzenberger, R. \& Tursic, J. (2008). Scientific Report COST 633, Particulate Matter - Properties Related to Health Effects.

International Agency for Research on Cancer. IARC monographs on the evaluation of carcinogenic risks to humans, volume 100 (E). A review of human carcinogens: Personal habits and indoor combustions. Lyon, France: IARC; 2012 Jan 1.

Kiesewetter, G., Borken-Kleefeld, J., Schöpp, W., Heyes, C., Thunis, P., Bessagnet, B., Terrenoire, E., Fagerli, H., Nyiri, A. \& Amann, M. (2015). Modelling street level PM10 concentrations across Europe: source apportionment and possible futures, Atmospheric Chemistry and Physics, 15(3), pp. 1539-1553.

Konieczyński, J. \& Pasoń-Konieczyńska, A. (1999). The aggregate emission index of air pollutants from hard coal combustion, Archiwum Ochrony Środowiska, 25(1), pp. 29-40. 
Nussbaumer, T., Czasch, C., Klippel, N., Johansson, L. \& Tullin, C. (2008). Particle emissions from biomass combustion in IEA countries. Survey on measurements and emission factors. (http:// www.ieabcc.nl/publications/Nussbaumer_et_al_IEA_Report_ PM10 Jan 2008.pdf. (09 April 2015)).

PN-G-04511 (1980). Solid fuels - Determination of Moisture. Polish Standard, 1980. (in Polish)

PN-G-04512 (1980). Solid Fuels - Determination of Ash Content by Gravimetric Method. Polish Standard, 1980. (in Polish)

PN-G-04513 (1981). Solid fuels - Determination of gross calorific value and calculation of net calorific value. Polish Standard, 1981. (in Polish)

PN-G-04571 (1998). Solid fuels - Determination of carbon, hydrogen and nitrogen contents using the automatic analysers - Macro method. Polish Standard, 1998. (in Polish)

PN-G-04584 (2001). Solid fuels - Determination of total sulphur and of ash sulphur content with the use of the automatic analysers. Polish Standard, 2001. (in Polish)

PN-ISO 10396 (2001). Stationary source emissions - Sampling for the automated determination of gas concentrations. Polish Standard, 2001. (in Polish)

PN-ISO 1928 (2002). Solid mineral fuels - Determination of gross calorific value by the bomb calorimetric method and calculation of net calorific value. Polish Standard, 2002. PN-ISO 1928 (2002). (in Polish)

PN-ISO 587 (2000). Solid mineral fuels - Determination of chlorine using Eschka mixture. Polish Standard, 2000. (in Polish)

PN-Z-04030-07 (1994). Air purity protection - Tests for dust content - Measurement of concentration and mass flow rate of particulate matter in waste gases by gravimetric method. Polish Standard, 1994. (in Polish).

Schmidl, C., Luisser, M., Padouvas, E., Lasselsberger, L., Rzaca, M. \& Ramirez-Santa Cruz, C., Handler, M., Peng, G., Bauer, H. \& Puxbaum, H. (2011). Particulate and gaseous emissions from manually and automatically fired small scale combustion systems, Atmospheric Environment, 45(39), pp. 7443-7454.

Schmidl, C., Marr, I.L., Caseiro, A., Kotianová, P., Berner, A., Bauer, H., Kasper-Giebl, A. \& Puxbaum, H. (2008). Chemical characterisation of fine particle emissions from wood stove combustion of common woods growing in mid-European Alpine regions, Atmospheric Environment, 42(1), pp. 126-141.

Simoneit, B.R.T. (2002). Biomass burning - a review of organic tracers for smoke from incomplete combustion, Applied Geochemistry, 17(3), pp. 129-162.

Seljeskog, M., Goile, F., Sevault, A. \& Lamberg, H. (2013). Particle emission factors for wood stove firing in Norway. Trondheim, SINTEF Energi AS.

Szewczyńska, M., Ekiert, E. \& Pośniak, M. (2006). Uncontrolled burning processes as sources of the formation of dioxins and furans, Bezpieczeństwo pracy: nauka i praktyka, 1, pp. 8-11. (in Polish)

Szkarowski, A. \& Janta-Lipińska, S. (2013). Examination of Boiler Operation Energy-ecological Indicators During Fuel Burning with Controlled Residual Chemical Underburn, Annual Set The Environment Protection, 15, pp. 981-995. (in Polish)

Watson, J.G., Chow, J.C. \& Houck, J.E. (2001). PM2,5 chemical source profiles for vehicle exhaust, vegetative burning, geological materials, and coal burning in Northern Colorado during 1995, Chemosphere, 43(8), pp. 1141-1151.

Zhang, Y., Schauer, J.J., Zhang, Y., Zeng, L., Wei, Y., Liu, Y. \& Shao, M. (2008). Characteristics of particulate carbon emissions from real-world chinese coal Combustion, Environmental Science and Technology, 42(14), pp. 5068-5073.

Zhang, J. \& Smith, K.R.(2007). Household air pollution from coal and biomass fuels in China: Measurements, Health Impacts, and Interventions, Environmental Health Perspectives, 115(6), pp. $848-855$.

\title{
Badania nad właściwościami pyłów z kotłów małej mocy opalanych węglem i stałymi biopaliwami
}

\begin{abstract}
Streszczenie: Celem pracy badawczej była ocena ilości i składu substancji zanieczyszczających emitowanych przez kotły małej mocy, wyposażone w samoczynny podajnik paliwa do komory spalania. Przeprowadzono badania porównawcze właściwości paliw, parametrów spalin, zawartości pyłu (popiołu lotnego) i gazowych substancji zanieczyszczających powietrze w emitowanych spalinach z kotła $\mathrm{CO}$ małej mocy spalającego węgiel kamienny (ekogroszek), pelety z drewna drzew iglastych, ze słomy zbożowej, z miskanta, z łusek słonecznika, korę drzew iglastych, ziarno owsa i ziarno jęczmienia. Ustalono wskaźniki emisji pyłu i gazowych substancji zanieczyszczających powietrze, pomocnych w ocenie udziału tego rodzaju kotłów w zanieczyszczeniu środowiska. Oceniając badany kocioł stwierdzono, że mimo osiągniętego postępu w konstrukcji, spaliny zawierają popiół lotny, ze znaczną zawartością węgla EC (black carbon), w ilości wpływającej na jakość powietrza.
\end{abstract}

